\title{
Organic aerosol in the summertime southeastern United States: components and their link to volatility distribution, oxidation state and hygroscopicity
}

Evangelia Kostenidou et al.

Correspondence to: Athanasios Nenes (athanasios.nenes@gatech.edu) and Spyros N. Pandis (spyros@chemeng.upatras.gr)

The copyright of individual parts of the supplement might differ from the CC BY 4.0 License. 
28 Table S1. Volatility distribution, average volatility and vaporization enthalpy for each

29 PMF factor and for the total OA.

30

\begin{tabular}{|c|c|c|c|c|c|}
\hline \multirow[t]{2}{*}{ OA Type } & \multicolumn{4}{|c|}{ Saturation Concentration $C^{*}\left(\mu \mathrm{g} \mathrm{m}^{-3}\right)$} & \multirow[t]{2}{*}{$\Delta H_{\text {vap }}\left(\mathrm{kJ} \mathrm{mol}^{-1}\right)$} \\
\hline & $10^{-1}$ & 1 & 10 & Average $C^{*}$ & \\
\hline \multicolumn{6}{|c|}{$a_{m}=1$} \\
\hline MO-OOA & 0.44 & 0.14 & 0.42 & $0.95 \pm 0.31$ & $89 \pm 10$ \\
\hline LO-OOA & 0.27 & 0.19 & 0.54 & $1.88 \pm 0.32$ & $58 \pm 13$ \\
\hline Isoprene-OA & 0.41 & 0.16 & 0.43 & $1.05 \pm 0.30$ & $63 \pm 15$ \\
\hline $\mathrm{BBOA}$ & 0.47 & 0.29 & 0.24 & $0.59 \pm 0.22$ & $55 \pm 11$ \\
\hline Total OA & 0.54 & 0.19 & 0.27 & $0.55 \pm 0.29$ & $86 \pm 9$ \\
\hline
\end{tabular}

\begin{tabular}{cccccc} 
& \multicolumn{7}{c}{$\boldsymbol{a}_{\boldsymbol{m}}=\mathbf{0 . 1}$} \\
\hline MO-OOA & 0.23 & 0.17 & 0.60 & $2.36 \pm 3.33$ & 100 \\
\hline LO-OOA & 0.52 & 0.18 & 0.30 & $0.59 \pm 3.17$ & $98 \pm 6$ \\
\hline Isoprene-OA & 0.60 & 0.10 & 0.30 & $0.49 \pm 3.53$ & $96 \pm 8$ \\
\hline BBOA & 0.64 & 0.19 & 0.17 & $0.34 \pm 2.48$ & $86 \pm 9$ \\
\hline Total OA & 0.65 & 0.09 & 0.25 & $0.40 \pm 3.53$ & 100 \\
\hline
\end{tabular}

\begin{tabular}{cccccc}
\multicolumn{7}{c}{$\boldsymbol{a}_{\boldsymbol{m}}=\mathbf{0 . 0 1}$} \\
\hline MO-OOA & 0.46 & 0.11 & 0.43 & $0.92 \pm 3.74$ & 150 \\
\hline LO-OOA & 0.40 & 0.06 & 0.54 & $1.41 \pm 3.32$ & $121 \pm 25$ \\
\hline Isoprene-OA & 0.32 & 0.12 & 0.56 & $1.72 \pm 2.93$ & $113 \pm 22$ \\
\hline BBOA & 0.32 & 0.35 & 0.32 & $1.00 \pm 2.47$ & 100 \\
\hline Total OA & 0.40 & 0.19 & 0.41 & $1.00 \pm 3.16$ & 100 \\
\hline
\end{tabular}

$a_{m}=1, \mathrm{CE}_{\mathrm{TD}}=0.9 * \mathrm{CE}_{\mathrm{BP}}$

\begin{tabular}{cccccc}
\hline MO-OOA & 0.41 & 0.24 & 0.35 & $0.86 \pm 2.97$ & $86 \pm 9$ \\
\hline LO-OOA & 0.42 & 0.29 & 0.28 & $0.73 \pm 3.69$ & $63 \pm 15$ \\
\hline Isoprene-OA & 0.39 & 0.25 & 0.36 & $0.95 \pm 2.70$ & $54 \pm 10$ \\
\hline BBOA & 0.52 & 0.46 & 0.02 & $0.32 \pm 1.89$ & $54 \pm 10$ \\
\hline Total OA & 0.19 & 0.19 & 0.62 & $2.64 \pm 4.5$ & $58 \pm 13$ \\
\hline
\end{tabular}


32 Table S2: Volatility distribution and average volatility for specific vaporization 33 enthalpies for each PMF factor and for the total OA.

\begin{tabular}{|c|c|c|c|c|}
\hline \multirow{2}{*}{ OA Type } & \multicolumn{4}{|c|}{ Saturation Concentration $C^{*}\left(\mu \mathrm{g} \mathrm{m}^{-3}\right)$} \\
\hline & $10^{-1}$ & 1 & 10 & Average $C$ \\
\hline \multicolumn{5}{|c|}{$\Delta H_{v a p}=50 \mathrm{~kJ} \mathrm{~mol}^{-1}$} \\
\hline MO-OOA & 0.00 & 0.05 & 0.95 & $9.00 \pm 3.96$ \\
\hline LO-OOA & 0.25 & 0.05 & 0.70 & $2.80 \pm 3.15$ \\
\hline Isoprene-OA & 0.35 & 0.05 & 0.60 & $1.78 \pm 3.15$ \\
\hline BBOA & 0.65 & 0.05 & 0.30 & $0.45 \pm 3.15$ \\
\hline Total OA & 0.05 & 0.05 & 0.9 & $7.08 \pm 3.15$ \\
\hline
\end{tabular}

$\Delta H_{\text {vap }}=80 \mathrm{~kJ} \mathrm{~mol}^{-1}$

\begin{tabular}{ccccc}
\hline MO-OOA & 0.35 & 0.15 & 0.50 & $1.41 \pm 3.15$ \\
\hline LO-OOA & 0.64 & 0.16 & 0.20 & $0.26 \pm 3.15$ \\
\hline Isoprene-OA & 0.75 & 0.05 & 0.20 & $0.28 \pm 3.15$ \\
\hline BBOA & 0.87 & 0.03 & 0.10 & $0.17 \pm 3.17$ \\
\hline Total & 0.45 & 0.25 & 0.3 & $0.71 \pm 3.15$ \\
\hline
\end{tabular}

$\Delta H_{\text {vap }}=100 \mathrm{~kJ} \mathrm{~mol}^{-1}$

\begin{tabular}{ccccc}
\hline MO-OOA & 0.60 & 0.04 & 0.36 & $0.58 \pm 3.95$ \\
\hline LO-OOA & 0.90 & 0.04 & 0.06 & $0.14 \pm 3.96$ \\
\hline Isoprene-OA & 0.95 & 0 & 0.05 & $0.13 \pm 3.54$ \\
\hline BBOA & 0.96 & 0.04 & 0.00 & $0.11 \pm 3.15$ \\
\hline Total OA & 0.76 & 0.04 & 0.2 & $0.27 \pm 3.16$ \\
\hline
\end{tabular}


46 Table S3. Saturation vapor pressure $\left(P^{o}\right)$ and saturation concentration $\left(C^{*}\right)$ (at $\left.298 \mathrm{~K}\right)$ for

47 various acids.

\begin{tabular}{|c|c|c|}
\hline Organic acid & $\begin{array}{l}P^{o}(298 K) \\
\left(\mathrm{Pa}^{*} 10^{-5}\right)\end{array}$ & $\begin{array}{c}C^{*}(298 \mathrm{~K}) \\
\left(\mu \mathrm{g} \mathrm{m}^{-3}\right)\end{array}$ \\
\hline \multicolumn{3}{|l|}{ Adipic acid } \\
\hline Bilde et al. (2003) & $0.73(0.4)$ & 0.43 \\
\hline Riipinen et al. (2007) & $0.78(0.43)$ & 0.46 \\
\hline Saleh et al. (2009) & $0.52(0.3)$ & 0.31 \\
\hline Yaws et al. (2003) & $0.78(0.43)$ & 0.46 \\
\hline \multicolumn{3}{|l|}{ Azelaic acid } \\
\hline Bilde et al. (2003) & $0.44(0.18)$ & 0.34 \\
\hline Yaws et al. (2003) & $0.81(0.3)$ & 0.62 \\
\hline \multicolumn{3}{|l|}{ Malonic acid } \\
\hline Bilde et al. (2003) & $8.35(1.78)$ & 3.5 \\
\hline Hyvärinen et al. (2006) & $7.45(1.58)$ & 3.1 \\
\hline \multicolumn{3}{|l|}{ Suberic acid } \\
\hline Bilde et al. (2003) & $0.05(0.14)$ & 0.036 \\
\hline \multicolumn{3}{|l|}{ Pimelic acid } \\
\hline Saleh et al. (2008) & $7.2(1.7)$ & 4.65 \\
\hline \multicolumn{3}{|l|}{ Oxalic acid } \\
\hline Booth et al. (2010) & $2150(860)$ & 780 \\
\hline \multicolumn{3}{|l|}{ Glutaric acid } \\
\hline Bilde and Pandis (2001) & $75(37)$ & 39.9 \\
\hline Bilde (2003) & $88(44)$ & 46.8 \\
\hline \multicolumn{3}{|l|}{ Succinic acid } \\
\hline Bilde 2003 & 3.93 & 1.9 \\
\hline Hyvärinen et al. 2006 & 4.97 & 2.4 \\
\hline Saleh 2009 & 4.31 & 2.1 \\
\hline Yaws 2003 & 4.77 & 2.3 \\
\hline \multicolumn{3}{|l|}{ Levoglucosan } \\
\hline May et al. (2012) & & $13(2)$ \\
\hline \multicolumn{3}{|l|}{ Pinonic acid } \\
\hline Bilde (2001) & 7 & 5.19 \\
\hline Salo et al. (2010) & $0.42(0.15)$ & 0.312 \\
\hline
\end{tabular}


54 Table S4. Hygroscopicity values ( $\kappa$ ) for the same acids as in Table S4. Values in 55 parenthesis represent standard deviations.

\begin{tabular}{ll}
\hline Organic acid & K \\
\hline Adipic acid & $0.022(0.002)$ \\
\hline Cerully et al. (2014) & $0.002(0.001)$ \\
Kuwata et al. (2013) & $0.059(+0.021 ;-0.014)$ \\
Rissman et al. (2007) & $0.03(+0.002 ;-0.001)$ \\
Huff Hartz et al. (2006) & $0.096(\mathrm{n} / \mathrm{a})$ \\
Broekhuizen et al. (2004) & $0.02(+0.018 ;-0.008)$ \\
Raymond and Pandis (2002) & $0.014(\mathrm{n} / \mathrm{a})$ \\
Prenni et al. (2001) & $0.03(\mathrm{n} / \mathrm{a})$ \\
Corrigan and Novakov (1999) & $0.099(+0.048 ;-0.029)$ \\
Cruz and Pandis (1997) & \\
\hline Azelaic acid & $0.061(0.007)$ \\
\hline Cerully et al. (2014) & $0.03(0.01)$ \\
Kuwata et al. (2013) & $0.022(+0.018 ;-0.009)$ \\
Huff Hartz et al. (2006) & \\
\hline Malonic acid & $0.281(0.034)$ \\
\hline Cerully et al. (2014) & $0.227(0.028)$ \\
Kumar et al. (2003) & $0.237(\mathrm{n} / \mathrm{a})$ \\
Prenni et al. (2001) & \\
\hline Suberic acid & $0.007(0.000)$ \\
\hline Cerully et al. (2014) & $0.001(\mathrm{n} / \mathrm{a})$ \\
Kuwata et al. (2013) & \\
\hline Pimelic acid & $0.213(0.016)$ \\
\hline Cerully et al. (2014) & $0.15(0.01)$ \\
Kuwata et al. (2013) & $0.15(0.04)$ \\
Frosch et al. (2010) & $0.14(+0.109 ;-0.054)$ \\
\hline Huff Hartz et al. (2006) & \\
\hline Oxalic acid & $0.5(0.05)$ \\
\hline Sullivan et al. (2009) & \\
\hline Glutaric acid & $0.195(0.082)$ \\
\hline Reymond and Pandis (2002) & $0.2(0.08)$ \\
\hline Koehler et al. (2006) & $0.285(0.029)$ \\
\hline Succinic acid & $0.231(0.065)$ \\
\hline Cerruly 2014 & 0.310 \\
\hline Hori (2003) & 0.225 \\
\hline Prenni (2001) & $0.208(0.015)$ \\
\hline Corrigan and Novakov (1999) & $0.165(0.015)$ \\
\hline Levoglucosan & $0.106(0.09)$ \\
\hline Svenningsson et al. (2006) & \\
\hline Koehler et al. (2006) & \\
\hline Pinonic acid & \\
\hline Raymond and Pandis (2002) & \\
\hline & \\
\hline
\end{tabular}



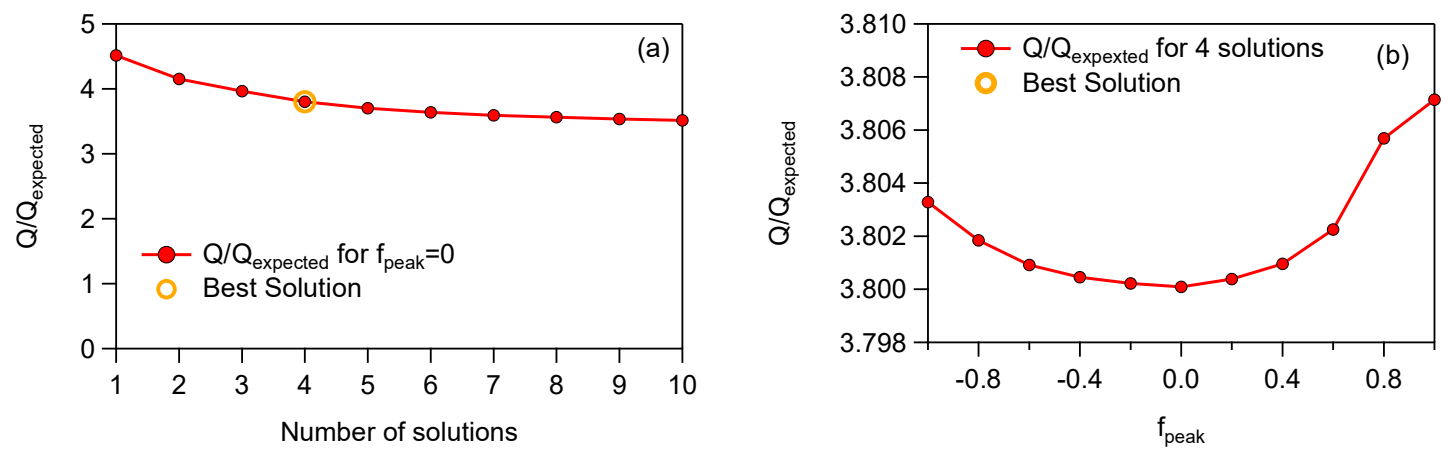

56
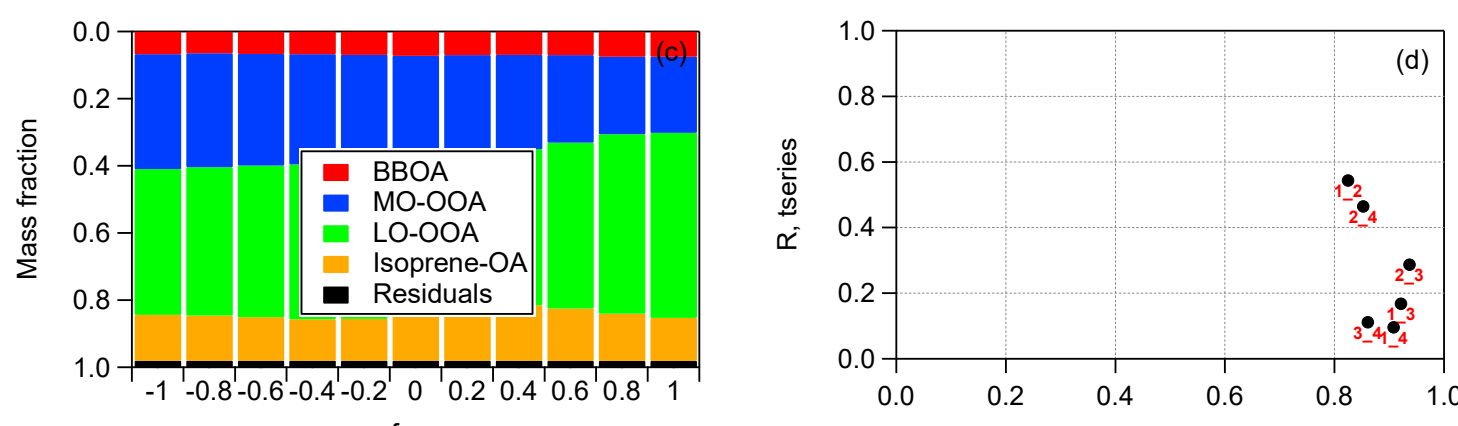

57

$f_{\text {peak }}$
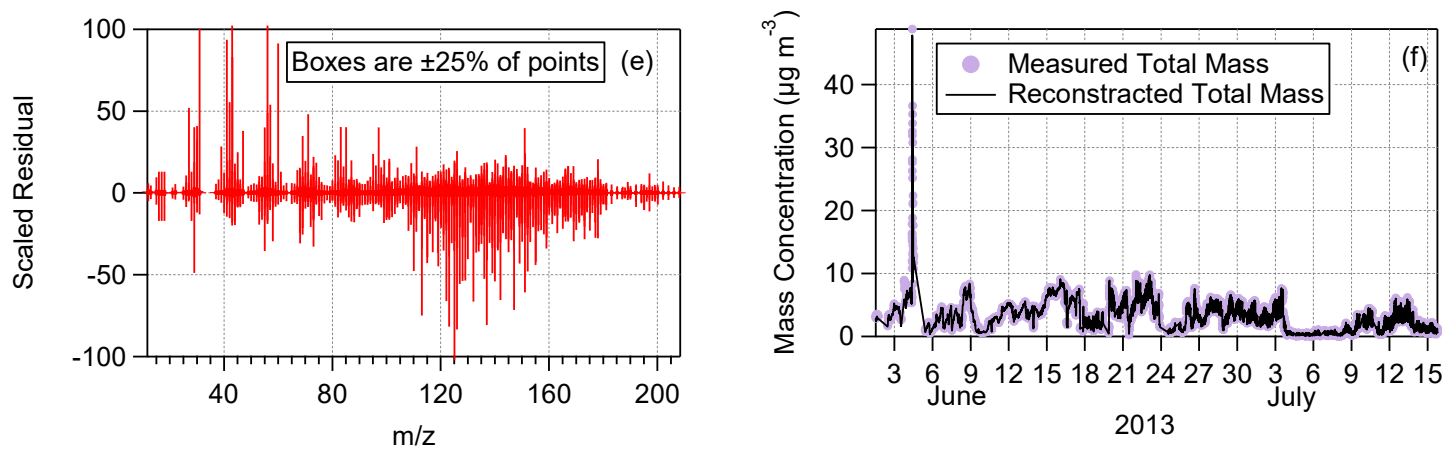

Figure S1. Diagnostic plots of the PMF analysis: (a) Q/Q expected versus the number of the

60 examined factors, (b) $\mathrm{Q} / \mathrm{Q}_{\text {expected }}$ versus the $\mathrm{f}_{\text {peak }}$ for the optimum solution (4 factors), (c)

61 mass fraction of PMF factors versus the $f_{\text {peak }}$, (d) correlations of time series and mass

62 spectra among the 4 PMF factors, (e) distribution of scaled residuals for each $m / z$ and (f)

63 time series of the measured and the reconstructed organic mass. 


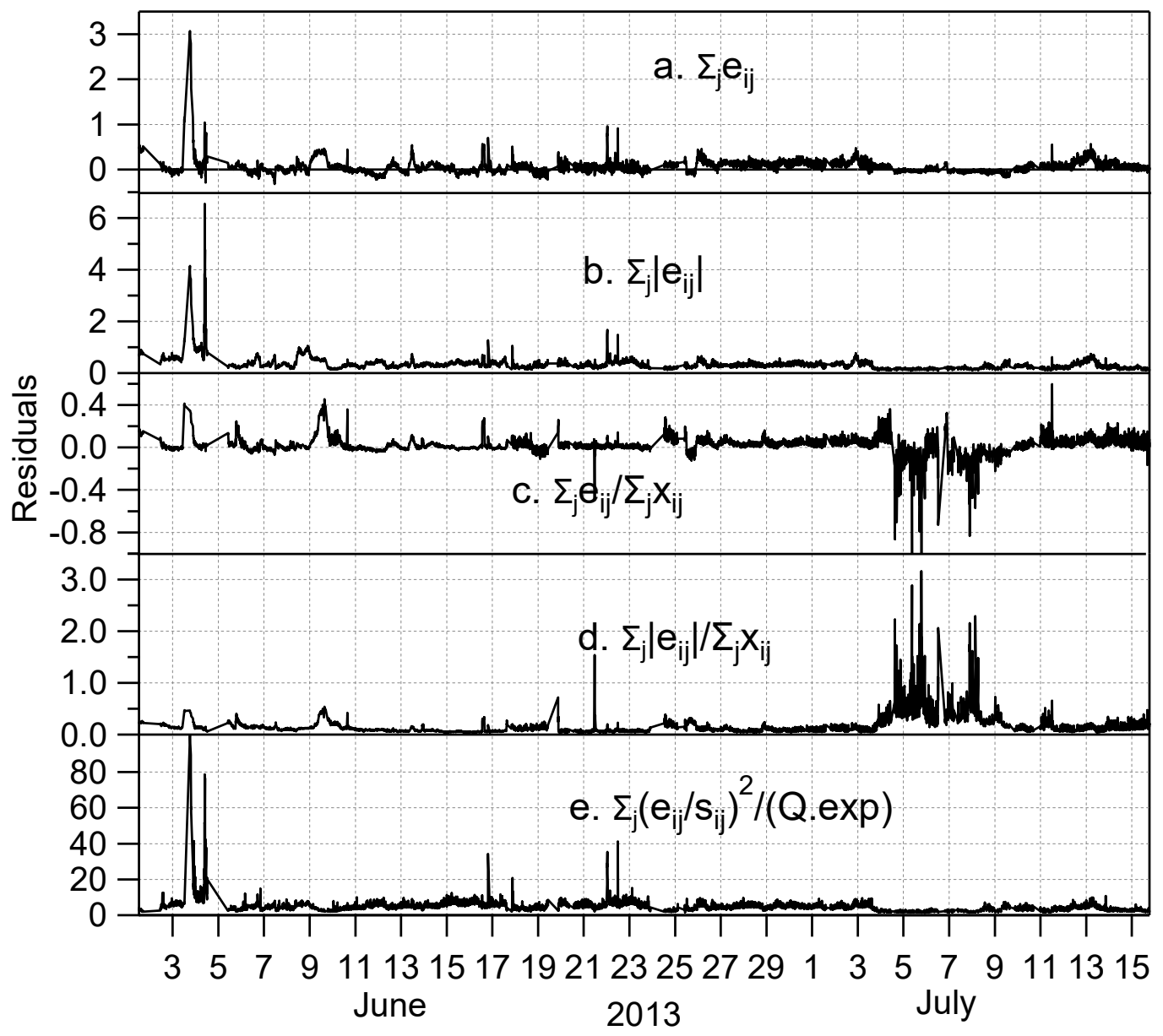

Figure S2. Model residuals $\mathbf{E}=\mathbf{X}$-GF calculated using the PMF evaluation tool, PET 72 (Ulbrich et al., 2009). 

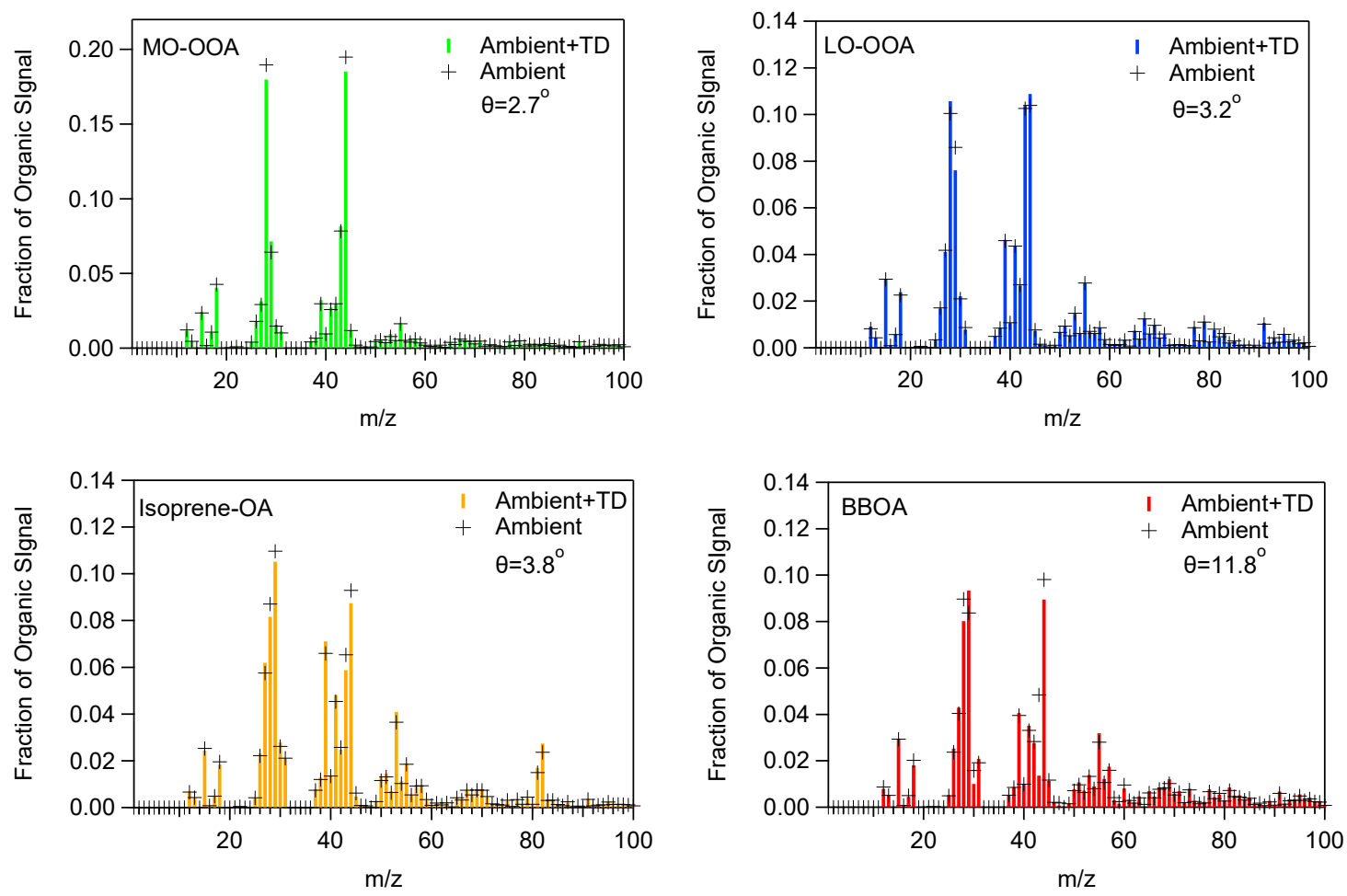

Figure S3. Comparison between the ambient PMF factors (crosses) as reported by Xu et

87 al. (2015) and ambient plus TD OA PMF factors (bars) found in this work.

88

89

90

91

92

93

94

95

96

97

98

99

100

101

102

103 

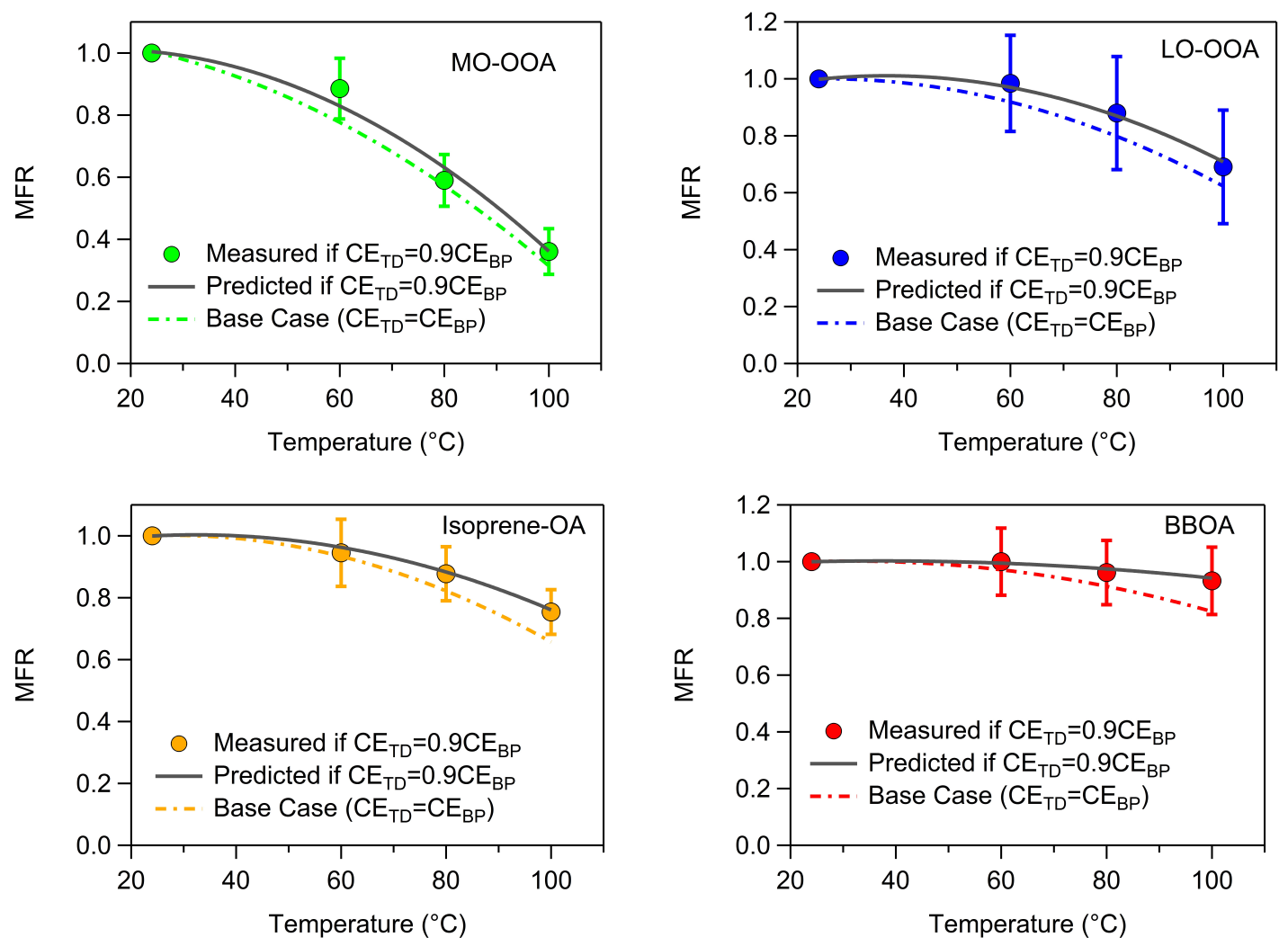

106

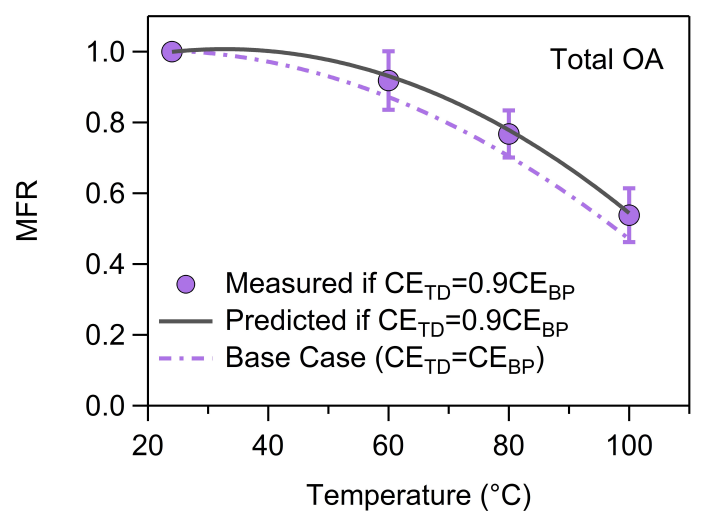

109 Figure S4. MFRs of the loss-corrected PMF OA factors and total OA for a lower TD CE.

110 The circles denote the measurements with the one standard deviation of the mean for a $11110 \%$ lower TD CE, the grey solid lines stand for the optimum solution if CE TD was 10\%

112 lower and the dash lines correspond to the predicted base case.

113 

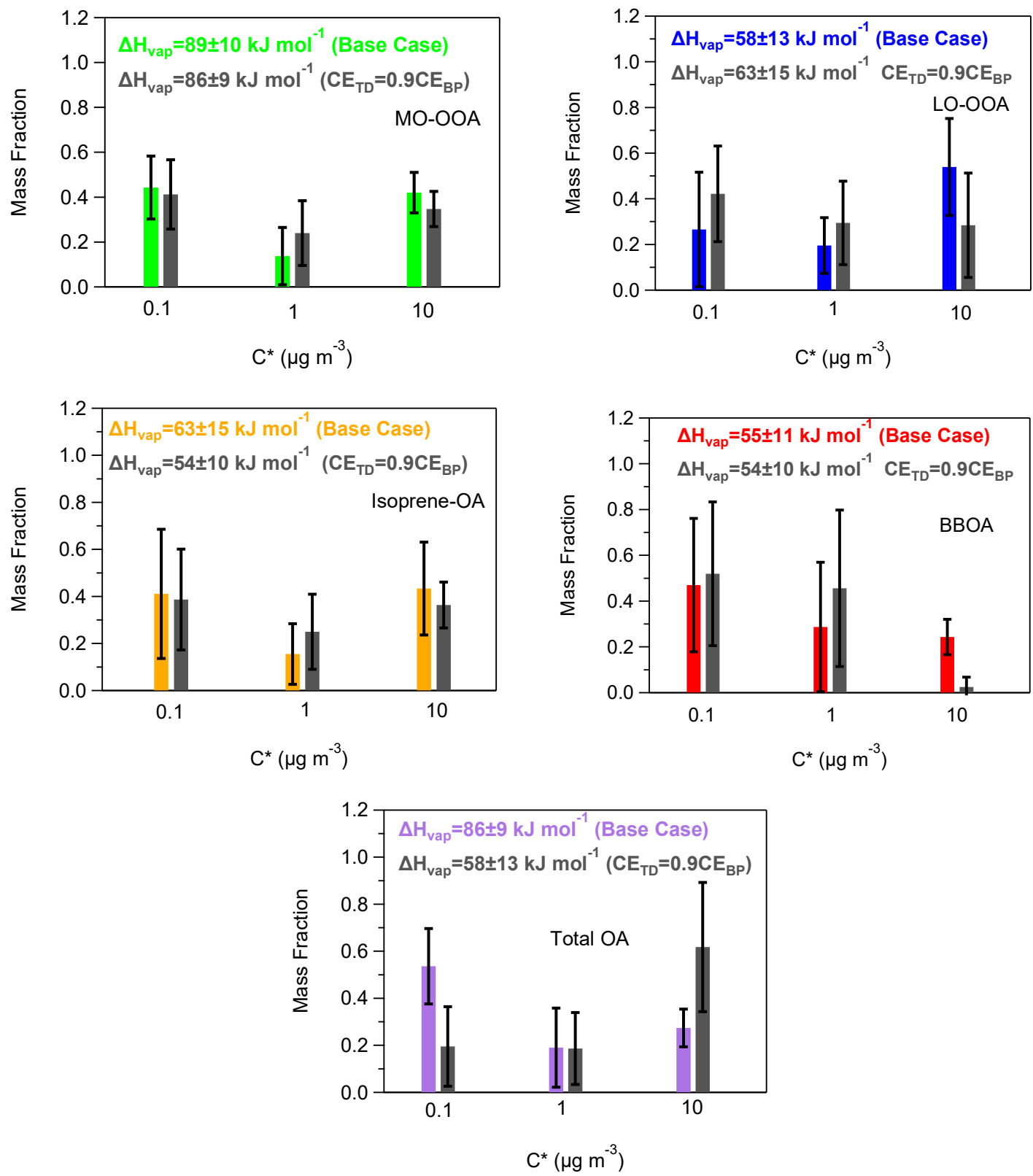

Figure S5. Predicted volatility distributions of the OA PMF factors and total OA for a

118 lower TD CE. The error bars are estimated using the approach of Karnezi et al. (2014).

119 The grey solid bars represent the results for a 10\% lower TD CE. The green, blue, orange,

120 red and purple bars stand for the base case solutions of MO-OOA, LO-OOA, Isoprene-

121 OA, BBOA and total OA. 

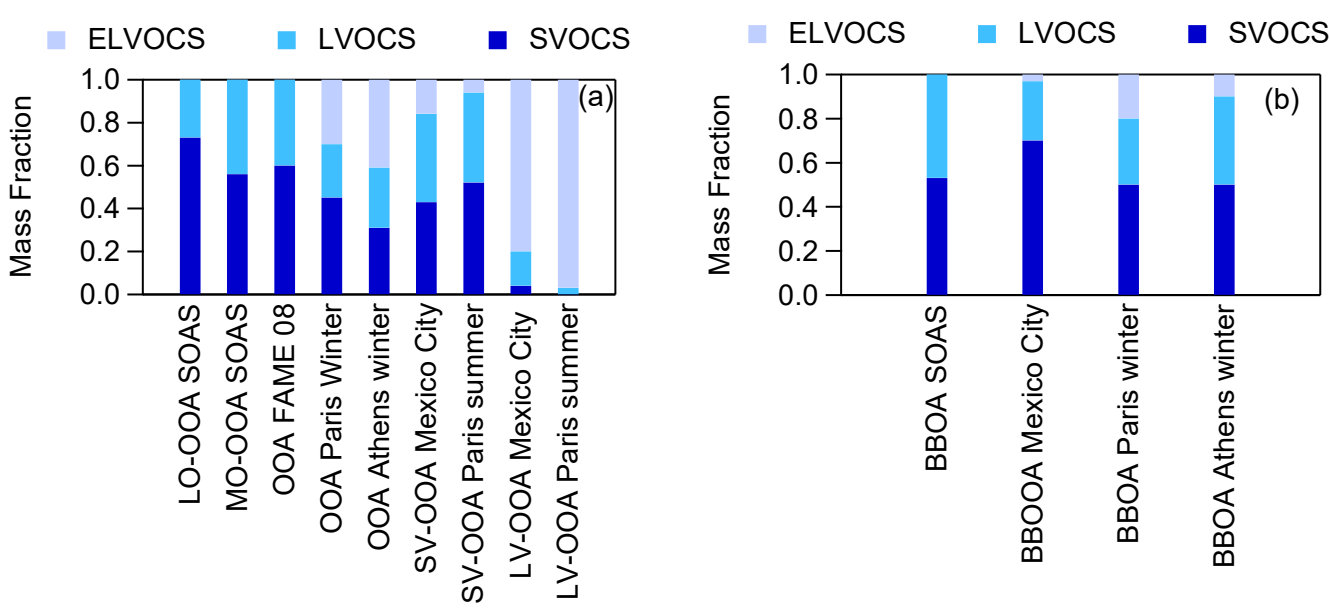

123
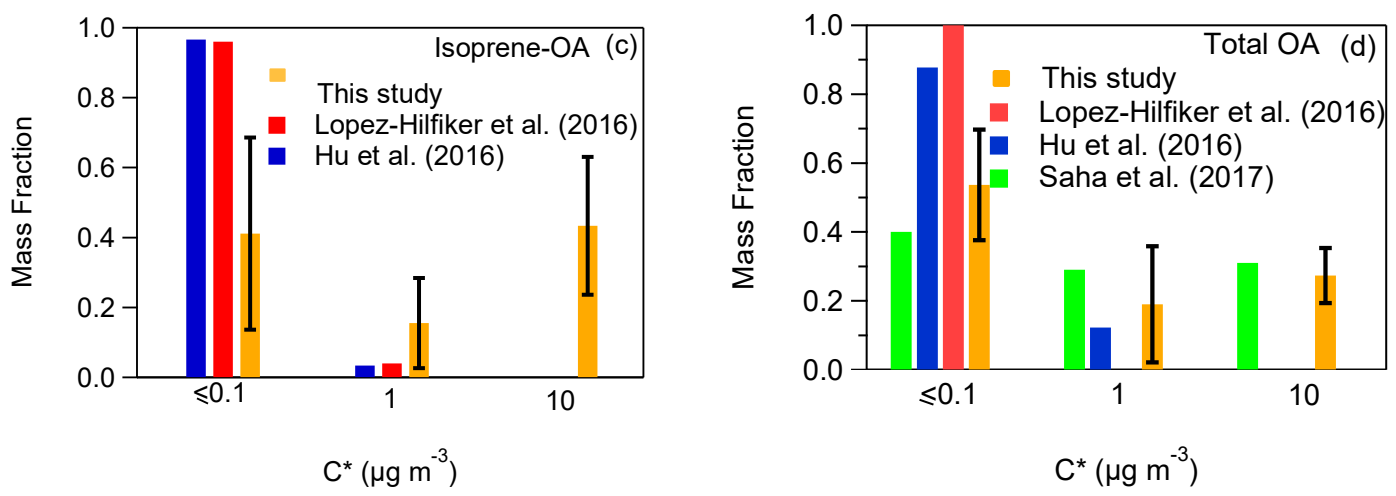

126 Figure S6. (a) and (b) Comparison between volatility compositions of OA for various 127 studies: MILAGRO (Mexico City), MEGAPOLI (Paris winter and summer), Athens 128 winter and FAME-08 (Finokalia, Crete). (c) and (d) Comparison between volatility 129 distributions of Isoprene-OA and total OA estimated by other groups in Centreville 130 during SOAS. 


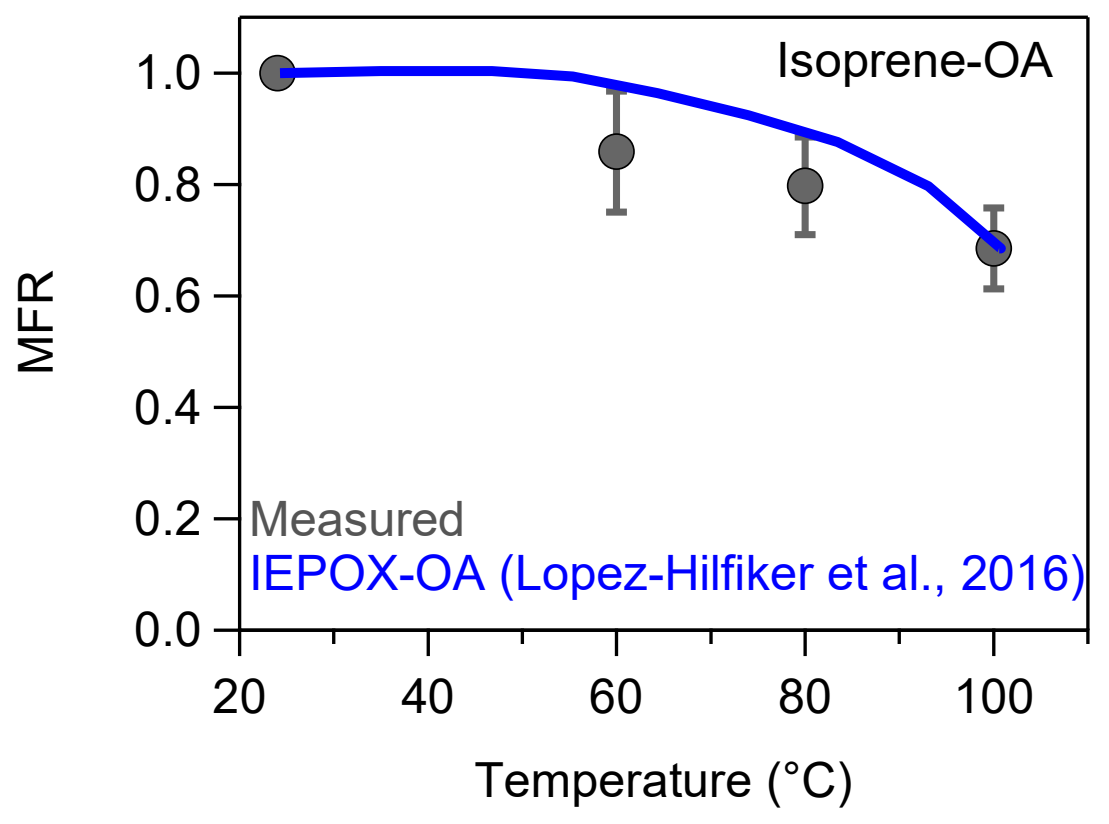

133 Figure S7. MFRs of the loss-corrected Isoprene-OA factor. The circles correspond to the 134 measurements with the one standard deviation of the mean. The blue line is the predicted 135 solution using as input the volatility distribution of IEPOX SOA of Lopez-Hilfiker et al. 136 (2016). 


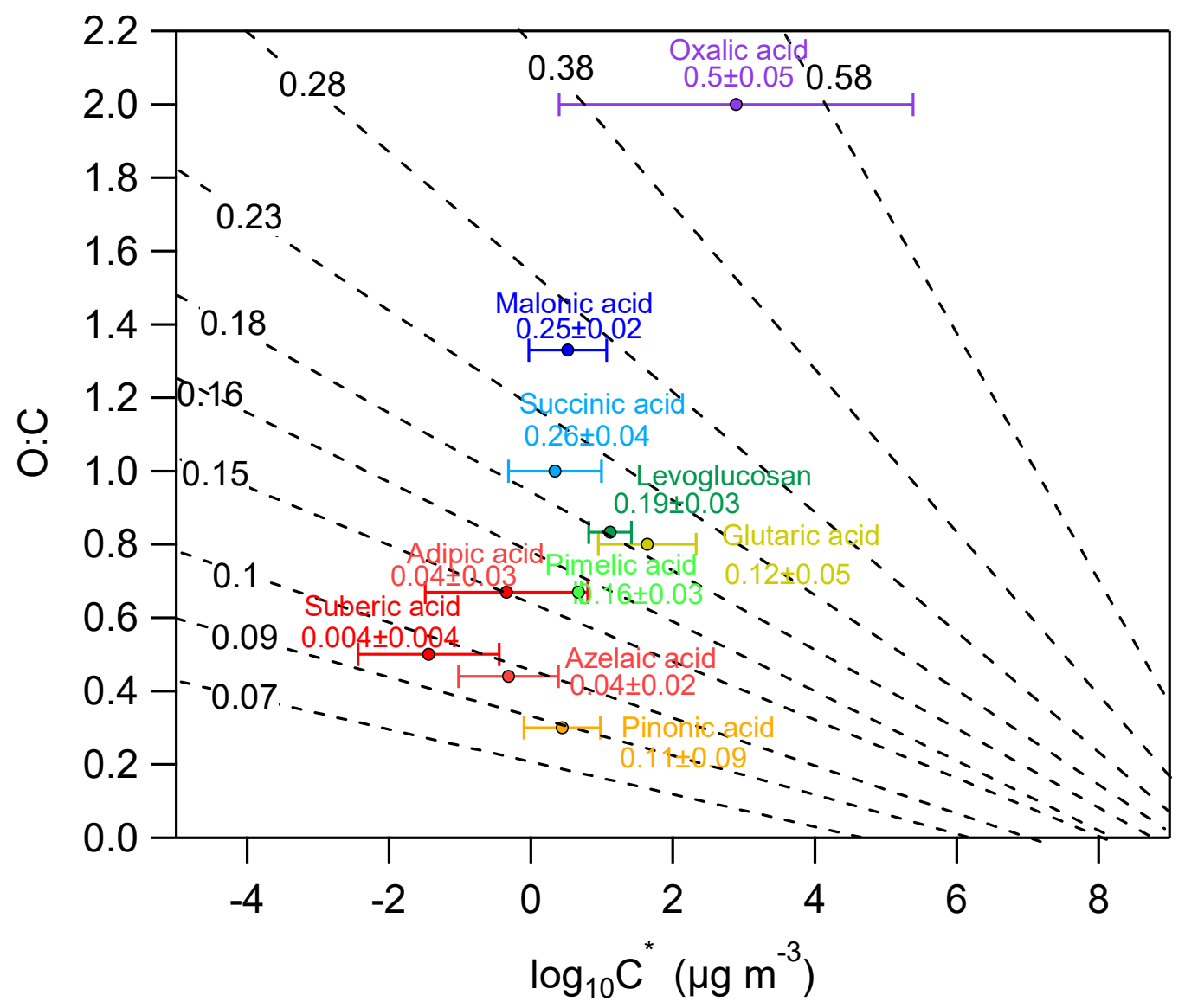

153 Figure S8. O:C ratios versus the average volatility as $\log _{10} \mathrm{C}^{*}$. The black isolines 154 correspond to the theoretically intrinsic $\kappa$ suggested by Nakao et al. (2017). The circles 155 stand for the volatility and hygroscopicity measurements of known compounds based on 156 Tables S3 and S4. 


\section{References:}

167 Bilde, M., and Pandis, S. N.: Evaporation rates and vapor pressures of individual aerosol species formed in the atmospheric oxidation of $\alpha$ - and $\beta$-pinene, Environ. Sci. Technol., 35, 3344-3349, 2001.

Bilde, M., Svenningsson, B., Mønster, J., and Rosenørn, T.: Even-odd alternation of evaporation rates and vapor pressures of C3-C9 dicarboxylic acid aerosols, Environ. Sci. Tech., 37, 1371, 2003.

Booth, A. M., Barley, M. H., Topping, D. O., McFiggans, G., Garforth, A., and Percival, dicarboxylic acids using Knudsen Effusion Mass Spectrometry (KEMS) and Differential Scanning Calorimetry, Atmos. Chem. Phys., 10, 4879-4892, 2010.

Broekhuizen, K., Kumar, P. P., and Abbatt, J. P. D.: Partially soluble organics as cloud condensation nuclei: Role of trace soluble and surface active species, Geophys. Res. Lett., 31, L01107, doi: 10.1029/2003GL018203, 2004.

Cerully, K. M., Hite, J., McLaughlin, M., and Nenes, A.: Towards the determination of joint volatility-hygroscopicity distributions: instrument development and response characterization for single-component aerosol, Aerosol. Sci. Tech., 48, 296-312, 2014.

Corrigan, C. E., and Novakov, T.: Cloud condensation nucleus activity of organic compounds: a laboratory study, Atmos. Environ., 33, 2661-2668, 1999.

Cruz, C. N., and Pandis, S. N.: A study of the ability of pure secondary organic aerosol to act as cloud condensation nuclei, Atmos. Environ., 31, 2205-2214, 1997.

Frosch, M., Zardini, A. A., Platt, S. M., Müller, L., Reinnig, M.-C., Hoffmann, T., and Bilde, M.: Thermodynamic properties and cloud droplet activation of a series of oxo-acids, Atmos. Chem. Phys., 10, 5873-5890, 2010.

Hori, M., Ohta, S., Murao, N., and Yamagata, S.: Activation capability of water soluble organic substances as CCN, J. Aerosol. Sci., 34, 419-448, 2003.

Huff Hartz, K. E. H., Tischuk, J. E., Chan, M. N., Chan, C. K., Donahue, N. M., and Pandis, S. N.: Cloud condensation nuclei activation of limited solubility organic aerosol. Atmos. Environ., 40, 605-617, 2006. 
Hyvärinen, A.-P., Lihavainen, H., Gaman, A., Vairila, L., Ojala, H., Kulmala, M., and Viisanen, Y.: Surface tensions and densities of oxalic, malonic, succinic, maleic, malic, and cis-pinonic acids. J. Chem. Eng. Data, 51, 255, doi:10.1021/je050366x, 2006.

Karnezi, E., Riipinen, I., and Pandis, S. N.: Measuring the atmospheric organic aerosol volatility distribution: a theoretical analysis, Atmos. Meas. Tech., 7, 2953-2965, 2014.

Koehler, K. A., Kreidenweis, S. M., DeMott, P. J., Prenni, A. J., Carrico, C. M., Ervens, B., and Feingold, G.: Water activity and activation diameters from hygroscopicity data - Part II: Application to organic species, Atmos. Chem. Phys., 6, 795-809, 2006.

Kumar, P. P., Broekhuizen, K., and Abbatt, J. P. D.: Organic acids as cloud condensation nuclei: Laboratory studies of highly soluble and insoluble species. Atmos. Chem. Phys., 3, 509-520, 2003.

Kuwata, M., Shao, W., Lebouteiller, R., and Martin, S. T.: Classifying organic materials by oxygen-to-carbon elemental ratio to predict the activation regime of Cloud Condensation Nuclei (CCN), Atmos. Chem. Phys., 13, 5309-5324, 2013.

Lopez-Hilfiker, F. D., Mohr, C., D’Ambro, E. L., Lutz, A., Riedel, T. P., Gaston, C. J., Iyer, S., Zhang, X., Gold, A., Surratt, J. D., Lee, B. H., Kurten, T., Hu, W. W., Jimenez, J., Hallquist, M., and Thornton, J. A.: Molecular composition and volatility of organic aerosol in the Southeastern U.S.: Implications for IEPOX Derived SOA. Environ. Sci. Technol., 50, (5), 2200-2209, 2016.

May, A. A., Saleh, R., Hennigan, C. J., Donahue, N. M., and Allen L. Robinson, A. L.: Volatility of organic molecular markers used for source apportionment analysis: Measurements and implications for atmospheric lifetime, Environ. Sci. Technol., 46, 12435-12444, 2012.

Nakao, S.: Why would apparent $\kappa$ linearly change with $\mathrm{O} / \mathrm{C}$ ? Assessing the Role of Volatility, Solubility, and Surface Activity of Organic Aerosols, Aerosol Sci. Tech., under revision, 2017. 
Prenni, A. J., DeMott, P. J., Kreidenweis, S. M., and Sherman, D. E.: The effects of low molecular weight dicarboxylic acids on cloud formation. J. Phys. Chem. A., 105, 11240-11248, 2001.

Raymond, T. and Pandis, S. N.: Cloud activation of single-component organic aerosol particles, J. Geophys. Res., 107, 4787, doi: 10.1029/2002JD002159, 2002.

Riipinen, I., Koponen, I. K., Frank, G. P., Hyvarinen, A.-P., Vanhanen, J., Lihavainen, H., Lehtinen, K. E. J., Bilde, M.., and Kulmala, M..: Adipic and malonic acid aqueous solutions: surface tensions and saturation vapor pressures. J. Phys. Chem., 111, 12995-13002, 2007.

Rissman, T.A., Varutbangkul, V., Surratt, J.D., Topping, D.O., McFiggans, G., Flagan, R.C., and Seinfeld, J.H.: Cloud condensation nucleus (CCN) behavior of organic aerosol particles generated by atomization of water and methanol solutions, Atmos. Chem. Phys., 7, 2949-2971, 2007.

Saleh, R., Walkerb, J., and Khlystov, A.: Determination of saturation pressure and enthalpy of vaporization of semi-volatile aerosols: The integrated volume method, Aerosol Science, 39, 876-887, 2008.

Saleh, R., Shihadeh A., and Khlystov, A.: Determination of evaporation coefficients of semi-volatile organic aerosols using an integrated volume-tandem differential mobility analysis (IV-TDMA) method. J. Aerosol Sci., 40, 1019-1029, 2009.

Salo, K., Jonsson, A. M., Andersson, P. U., and Hallquist, M.: Aerosol volatility and enthalpy of sublimation of carboxylic acids. J. Phys. Chem. A., 114, 4586-4594, 2010 .

Sullivan, R. C., Moore, M. J. K., Petters, M. D., Kreidenweis, S. M., Roberts, G. C., and Prather, K. A.: Effect of chemical mixing state on the hygroscopicity and cloud nucleation properties of calcium mineral dust particles, Atmos. Chem. Phys., 9, 3303-3316, 2009.

Svenningsson, B., Rissler, J., Swietlicki, E., Mircea, M., Bilde, M., Facchini, M. C., Decesari, S., Fuzzi, S., Zhou, J., Mønster, J., and Rosenørn, T.: Hygroscopic growth and critical supersaturations for mixed aerosol particles of inorganic and organic compounds of atmospheric relevance, Atmos. Chem. Phys., 6, 1937-1952, 2006. 
256 Ulbrich, I. M., Canagaratna, M. R., Zhang, Q., Worsnop, D. R., and Jimenez, J. L.: 257 Interpretation of organic components from Positive Matrix Factorization of 258 aerosol mass spectrometric data, Atmos. Chem. Phys., 9, 2891-2918, 2009.

259 Yaws, C. L.: Yaws' Handbook of thermodynamic and physical properties of chemical 260 compounds, 2003.

261 Xu, L., Guo, H., Boyd, C. M., Klein, M., Bougiatioti, A., Cerully, K, M., Hite, J. R., 262 Isaacman-VanWertz, G., Kreisberg, N. M., Knote, C., Olson, K., Koss, A., 263 Goldstein, A. H., Hering, S. V., de Gouw, J., Baumann, K., Lee, S-H., Nenes, A., 264 Weber, R. J., and Ng, N. L.: Effects of anthropogenic emissions on aerosol 265 formation from isoprene and monoterpenes in the Southeastern United States, P. $266 \quad$ Natl. Acad. Sci., 112, 37-42, 2015. 